which have actively worked for the benefit of agriculture, forestry, and fisheries.

Mr. W. R. Barker, chairman of the Museum and Art Gallery Committee, said the committee of that institution recognises the beneficial effect of active cooperation with the University College of Bristol, and to that end is rapidl, developing a special section of economic biology for the exhibition of insect and plant pests, and of material damaged by them. Prof. A. F. Stanley Kent explained that the new department has been calied into existence by the needs of the west of Englard, and that applications for help and inquiry have come in rapidly. Valuable research work has already been carried on at the college in matters relating to economic biology, and important results have been obtained in connection with ciders, blackcurrant disease, and the development of lobsters on the coast of Devon and Cornwall. It was announced that Mr. Richardson Cross has offered land for an experimental station, where investigations upon various crops, manures, \&c., can be carried on; additional land has also been offered by Mr. James Sinnott at St. Anne's Park. It is intended that the teaching side of the work shall be kept subsidiary to the advisory, and that the real function shall be to supply information and render help wherever required. Prof. Lloyd Morgan pointed out that academic and national interesis in these matters are one, and that the department will directly benefit the community. Mr. W. E. Collinge (Birmingham) described the work of his department in the University of Birmingham, instancing as an example of the work done the yield from two orchards of the same acreage, and only separated by a road. One left unsprayed produced fruit worth $122 l$. the other, that had been sprayed, produced fruit worth 497 .

\section{SYNTHETICAL CHEMISTRY IN ITS RELATION TO BIOLOGY}

$\mathrm{T}^{\mathrm{T}}$ is easy to understand why in its early youth organic chemistry was so closely connected with biology; the materials which the chemist was called upon to investigate were mostly products of aninal or vegetable origin. Indeed, carbon.trates, proteins, and vegetable acids served Lavoisier, Gay-Lusize, Borzelius, and Liebig as materials in elaboratin the thods of elementary analysis.

The isolation of Whe from animal urine by Rouclle, the recognition of urid acid, lactic acid, malic acid, and glycerine by Scherle, the isolation of asparagine by Vauquelin and Robiquet, of morphine by Serturnier, together with many other similar discoveries accomplished during the first ten years of the nineteenth century, are admirable examples of the manner in which the living world was drawn upon and made to rield up its treasur of chemical compounds. The many hundreds of natural organic compounds enumerated in the text-books of animal and vegetable chemistry are proof of the rich harvest since gathered in this field of investigation; but how small is their number when compared with the r 30,000 carbon compounds which organic chemistry can boast of to-day. All these, it is known, are either products of the artificial transformation of organic matters occurring naturally or have been completely synthesised from their elements. The accumulation of this huge material, including the elaboration of the necessary methods, has been the main occupation of organic chemists during the past sixty years; and as their discoveries gave rise to much happy speculation, for the time being they took the lead in developing chemical theory.

It is not to be denied that, in the latter half of the last century, owing to the growth of the subiect in importance, organic chemistry became separated from biology. It cannot be mere chance that the most famous of Liebig's pupils, A. W. Hofmann, A. Kekulé, and A. Wurtz, did not follow the example of their great teacher, whose chief triumphs were won by the use he made of chemical methods in solving biological problems. Perhaps they were restrained by the feeling that, mainly through his

1 Abridged from the Faradav locture delivered by Prof. Emil Fischer, $F, R . C$. at a meeting of the Chemical Society held at the Royal Institution on Friday, October 18 .

NO. I982, VOL. 76] influence, physiological chemistry had been developed into a separate discipline, which should be cared for by men who could devote thernselves entirely to its service. Such subdivision of labour undoubtedly has many advantages; the disadvantages would have outweighed these had it precluded interchange of experiences and friendly cooperation of workers in the two fields; the history of both sciences, however, afferds ample proof that such has not been the case.

Phy iologisis have ever been ready to avail themselves of the latest developments "of chemical analysis and synthesis, whilst organic "chemists have not only been stimulated in many ways by biologists, but their studies have derived much practical aid from biological science. I may instance the modern development of the chemistry of fermentation, which began with the pioneer work of Pasteur, and was greatly favoured by the introduction of Koch's refined bacteriological methods; also the flourishing industry to which the manufacture of medical remedies prepared by synthetic methods has given rise.

But organic chemistry will certainly never be content to act as the mere handmaid of biology. This is impossible, as the theoretical and technical problems which she is already called upon to consider are too numerous, and they cannot fail to increase in number and importance in the future; but $I$ do consider it not only possible, but desirable, that the close connection of chemistry with biology which prevailed in the days of Liebig and Dumas should be re-established, as the great chemical secrets of life are only to be unveiled by cooperative work. I will therefore attempt to indicate the part chemistry can play by reference to cases of which 1 can claim to have personal experience.

We know that in nature the construction of organic matter begins in the leaves of plants with the conversion of carbon dioxide into sugar, from which many physiologists suppose "the complex substances contained in the living cell are formed by further changes in which nitrogen, sulphur, and phosphorus take part.

These transformations are for the most part enveloped in mystery. We know nothing definitely even of the assimilation of carbon dioxide. Of the various hypotheses advanced to explain the change, that advocated by A. von Bacyer has gained most support, namely, the view that the initial product is formaldehyde, glucose being formed from this by a process of polymerisation. Actually both changes have been effected artificially. $\Lambda$ fter it had been shown by Butleroff that on heating formaldehyde with lime water a sugar-like, syrupy product is formed, and O. Loew had improved the method of effecting the condensation, I was able to adduce proof that the complex mixture contains a sinall quantity of an $\alpha$-acrose which can be transformed into glucose. As it was known that carbon dioxide could be converted into formaldehyde by more or less drastic means, the preparation of glucose from carbon dioxide thus became a possibility. Recently. Fenton has surcecded in carrying out the reduction of carbon dioxide to formaldehyde at a low temperature in aqueous solution, so that it is now possible to effect the complete synthesis of sugar at temperatures such as prevail in the living plant. But how thorough is the work of the plant in comparison with our laboratory practice; usually when such questions are discussed, the poor yields which our methods give rise to are forgotten!

I need only allude here to recent apparently successful attempts, on the one hand, to effect the reduction af carbonic acid to formaldehyde by means of light, and. on the otiner, to detect formaldehyde in green leaves, as Prof. Meldola dealt exhaustively and critically with these questions in his presidential address eighteen months ago. I may be allowed, however, to dweli somewhat on. one peculiar feature of the natural change, ,, namely, the asymmetric character of the synthesis: according to preserit experience, and especially the brilliant investigations oi H. Brown and Morris, the optically active hexoses of the $d$-series, glucose and fructose. are alone formed.

But from the experience gained in effecting sintheses in the sugar group, as I showed some time ago, it is possible to give a fairly satisfactory explanation of this change. It is only necessary to assume that the condensation is preceded by the formation of an additive compound of 
formaldehyde with some optically active constituent of the chlorophyll granules. I shall give a more precise form to this hypothesis if I say that I consider it probable that the carbon dioxide itself enters into combination in this manner, as there is reason to suppose that the proteins offer sufficient opportunity for its fixation; according to Siegfried, even the simple amino-acids are capable of combining with carbon dioxide. I am inclined to think that this compound with carbon dioxide undergoes decomposition into oxygen and a reduction product, probably a derivative of formaldehyde; the condensation to sugar takes place either in the original asymmetric complex or in one produced from it by a secondary change involving the separation of the formaldehyde and its re-association in some other manner. It may be that the condensation takes place directly or that intermediate compounds, biose or glycerose, are formed. Thanks to the researches of Marckwald, and especially those of Mackenzie, we are acquainted with a whole series of asymmetric syntheses; no one of these, however, is half so complete as that involved in the formation of sugar under natural conditions. Indeed, it is obvious that if the natural process is to be imitated in vitro, it will be necessary to alter the methods hitherto adopted in every single detail; difficult as this may appear, it is not altogether impossible.

But even if this be done successfully, the precise nature of the assimilation process will not be finally elucidated. It is to be expected that this will only be accomplished when biological research, aided by improved analytical methods, has succeeded in following the changes which take place in the actual chlorophyll granules.

The carbohydrates elaborated by the plant undergo combustion to carbon dioxide and water in the animal body. The change is easily effected by means of powerful oxidising agents at the ordinary temperature; the natural process, however, must be a very different one, as in the organism oxygen is conveyed to the carbohydrate by oxidising enzymes, and doubtless many intermediate products are formed of which we know little at present.

It would be easy to multiply examples; but these two are sufficient to demonstrate the incompleteness of the explanation of biochemical processes deduced from the data of organic chemistry. The service rendered to biology by chiemical analysis and synthesis, which will be rendered by it in even greater measure in the future, is to be sought in other directions.

The ultimate aim of biochemistry is to gain complete insight into the unending series of changes which attend plant and animal metabolism. To accomplish a task of such magnitude, complete knowledge is required of each individual chemical substance occurring in the cycle of changes and of analytical methods which will permit of its recognition under conditions such as exist in the living organism. As a matter of course, it is the office of organic chemistry, especially of synthetic chemistry, to accumulate this absolutely essential material. The chemical constitution of hundreds of carbon compounds which occur naturally has already been determined, and their more important properties have been established; but far more remains to be done. In proof of this; let me briefly direct your attention to the three great classes of substances which predominate in the living world: the fats, the carbohydrates, and the proteins.

It was established at least ninety years ago by Chevreul, in the course of his celebrated investigations into the process of soap-making, that the fats can be decomposed into the glycerine discowered by Scheele and into fatty acids; but the relationship of these latter to one another could not be understood until the conception of homologous series had been evolved in organic chemistry. The classical researches of Berthelot and the discovery of glycol by 'Wurtz were necessary preliminaries to the establishment of the constitution of glveerine; the final proof that the fats are neutral glyceric salts of the fatty acids was first provided by Berthelot's synthesis. Synthetic methods have made us acquainted. with the mono- and di-glycerides and also with mixed triglycerides such as have frequentiy been met with of late in nature.: Nevertheless, the group in which the natural fats are ranged is one in which there are still many laounz and many misstatements to be corrected.

No. 1982 , voL. 76$]$
The problems afforded by the fats are simple, however, in comparison with those connected with the carbohydrates. The original subdivision of the group into mono-; di-, tri-, and poly-saccharides has been justified in practice. Up to the present time only the monosaccharides have been studied satisfactorily from the point of view of their spatial structure. The growth of our knowledge of the monosaccharides has proved in many ways to be of importance in connection with biological inquiry, especially in enabling us to penetrate the mystery of enzyme action somewhat further.

On contrasting the effects which emulsirr and the enzymes in yeast produce on the various glucosides prepared by synthetic methods, I was led to conclude, not only that there was a difference between the two series of optical antipodes similar to that discovered by Pasteur in the course of his studies of moulds, but that very slight changes in configuration were sufficient to inhibit the action of enzymes entirely. I was led by these observations to apply the simile of lock and key as an expression of the close inter-relationship in configuration which obtains between the enzyme and the substance which it attacks. Similar results were obtained on investigating the behaviour of the stereoisomeric hexoses with yeast, the fermentative power of which we now attribute to an enzyme-E. Buchner's zymase.

The experience gained with the glucosides became of service in studying the polysaccharides. Another outcome of the investigation has been the discovery of distinct enzymes capable of attacking di- and tri-saccharides. As the result of these inquiries. I was able to formulate: a rule of general biological significance, namely, that the alcoholic fermentation of a polysaccharide is necessarily preceded by its hydrolysis by some particular enzyme. It was shown, especially in the case of the invertase of Monilia Candida, that it is not essential that the enzyme should even be soluble in water.

Unfortunately, but few successful syntheses of polysaccharides have been effected. It is most desirable, therefore, that better methods should be devised, as it is probable that the attack on the dextrins, gums, and similar undeciphered substances is most likely to be successful if made from the synthetic side. It is to be expected that biology would gain much by the discovery and utilisation of such materials; more, perhaps, than it has from the study of the monosaccharides and of the glucosides prepared by artificial means.

The carbohydrate group is that in which use was first made of enzymes as synthetic agents. Such syntheses fascinate the imagination, as they approximate closely to natural processes; but I may point out that they cannot take the place of purely chemical methods, as these latter are so much more under our control and can be varied in so many ways that we are in the position to produce materials which it is quite impossible for the organised world to furnish. Laboratory synthetic methods will be indispensable for a long time to come, not only for preparative purposes, but also as the means of elucidating the structure of complex substances of natural origin.

This contention is applicable to the proteins even more than it is to the carbohydrates; as they are among the most complex substances produced in the living world and are concerned in all the vital activities of the cell; a complete comprehension of their nature must obviously precede the full development of biological chemistry. We distinguish to-day some forty to fifty natural proteins, discovered by the joint labours of chemists and physiologists; but it is to be expected that as the methods of differentiating and separating them are improved, their number will be largely increased.

At present the majority are known only in an amorphous form; some important terms of the group, however, such as oxyhæmoglobin, egg albumin and: the albumin of horse serum, excelsin from the Brazil nut, and the edestins from other plant seeds, have been obtained in definite crystals; but, unfortunately; it cannot be decided from their crystalline appearance whether these products are definite substances, as the tendency to form mixed crystals is the greater the more complicated the molecule. Examples in point are afforded by the aniline dyes, the higher fatty acids, and the purine compounds; 
and those who have studied the chemistry of the natural silicates will be aware of the extension which mineralogists have been compelled to give to the conception of isomorphism. It would therefore be altogether surprising if the crystallised natural proteins should turn out to be single substances.

Of the numerous attempts to unravel the constitution. of the proteins by analytical means, the only. method which has given useful results hitherto is that of hydrolysis. Hydrolysis can be effected by acids or by alkalis, and also by digestive enzymes; the products, it is well known, besides ammonia, are albumoses, peptones, and ultimately amino-acids. The wide range of variation in composition of these amino-acids is shown by examining a list of all the substances hitherto prepared from the proteins.

The proportions in which the various amino-acids are obtained from the different proteins vary very considerably. In some cases they are altogether lacking, as may be proved by application of the definite tests for tyrosine, tryptophane, or glycine; but it is worthy of note that, as a rule, the amino-acids isolated from the' mixtures produced by subjecting albuminous substances to hydrolysis all occur almost without exception, especially is this true of the important proteins which play the chief part in animal or vegctable metabolism, so that the conclusion must be drawn that none of them can be dispensed with in organic life. With the exception of diaminotrihydraxydodecanoic acid, they have all been so thoroughly investigated that their structure is well established. The majority also have been synthesised, proof of their structure having, in fact, been given in this way. Only oxyproline, histidine, and diaminotrihydroxydodecanoic acid remain still to be synthesised.

With the exception of glycine, all the amino-acids derived from natural sources are optically active; but when prepared by ordinary synthetic methods, as is well known they are obtained in the first instance in the racemic form. The resolution of the raccmoids into their optically active components has been effected quite recently in most cases. Asnaragine, however, which is closely related to aspartic acid, had been resolved into the two active forms by recrystallising the inactive synthetic product from water and separating the two constituents mechanically. Moreover, in the case of some other amino-acids, for example. leucine, the antipode of the natural form had been obtained bv partially fermenting the synthetic product with moulds. The complete synthesis of the active amino-acids which are abtained from natural sources was first accomplished by the method I introduced based upon the use of the acyl derivatives. The method has been applied with success to the majority of the synthetic products; its extension to the remaining cases, proline, lysine, tryptophane. and cystine, is not likely to be attended with any difficulties.

As the amino-acids are formed from the proteins, not only when these are subjected to the action of hot acids and alkalis. but also at moderate temperatures by the agency. of the digestive enzymes, ther are to be regarded as the, true foundation stones of protein molecules. Opinions adverse to this hypothesis are only occasionally met with; they centre round the arbitrary sunnosition that complicated atomic re-arrangements may take place during hvdrolysis.

Were one inclined to regard such objections as of moment, all the experiments on the determination of the constitution of organic compounds by degradation methods would be uscless: moreover the conclusions, which have been drawn in other cases from the restits obtained by the dissection of compounds have been ton frequentlv ron. fremed by their synthesis. It is now possible to make this claim on behalf of the prateins, as it has been found to be possible. hv, a process the reverse; af hudrolysis, to associate amino-acids in such a manner-that substances are produced whirh, in the case of the simpler terms, closely resemble peotnnes. whilst the more complex resenble proteins.

$I$ have termed these synthetic produrts polvbeptides. in view of their relationshin to the peptones and to farilitate systematic treatment of the group on the lines of the carbohydrates.

No useful purpose will bf served by my giving an account of the surithefical methods nn the present necasion, especially as 1 had the honour six months ago, of de- scribing to you the preparation of an octadecapeptide derived from fifteen molecules of glycine and three motecules of $l$-leucine, a substance which in its external properties closely resembles many natural proteins. I may say that more than one hundred of these artificial polypeptides have already been synthesised.

Many of them, it is true; belong to the lower stages, but all the amino-acids previously mentioned, with the exception of diaminotrihydroxydodecanoic acid, have been made use of in their preparation. The synthesis of the higher terms has been westricted hitherto to the combin. ations of glycine, alanine, and leucine; there is not.a shadow of doubt, however, that all the remaining aminoacids could be associated in complicated systems with the aid of our present methods. The knowledge of the artificial polypeptides thus acquired has opened up new ways of investigating the peptones and albumoses analytically. During more than fifty years, physiological chemists have endeavoured without much success to isolate homogeneous substances from these ill-defined materials ; all the products described by them, however, bear indubitable evidence of being mixtures. By making use of new methods based on the study of the polypeptides, it has been possible during the last two years to isolate and detect with certainty quite a number of dipeptides among the decomposition products of the proteins.

In spite of encouraging successes, I am fully aware of the difficulty of discovering the nature of all the components of the various peptones and albumoses; but in preparing the way for the synthesis of the natural proteins this is not even necessary. Probably the werk can be restricted to the reconstruction of the original system from the major products of cleavage formed in the process of hydrolytic dissection. I am indeed venturesome enough to cherish the hope that I may be able to solve this problem in the case of silk fibroin, one of the simplest proteins. To deal with the whole of the proteins will be a gigantic task; so large a number of separate investigations will be necessary that nothing less than the lifework of a whole army of inventive and diligent chemists will suffice to complete it. Probably, too, the unplcasant discovery will be made that the natural proteins. as we know them to-day are only to be obtained by mixing the homogeneous artificial products.

I have sketched this prospect merely to indicate the manner in which synthesis must play the leading part in this field of work. The nature of the more complicated carbohydrates, as I have already pointed out, will also have to be determined in the future, I imagine, mainly by the application of synthetic methods. Obviously the conditions are very similar in the case of the dextrins and gums to those met with in the case of the proteins, and starch, which has hitherto been regarded as a homogeneous substance, appears also to come into the same category according to Maquenne's observations.

Not only do the proteins constitute the major part of living protoplasm, but they appear also to be the material from which the organism prepares its most wonderful agents - the ferments or enzymes. In many. of the more thoroughly investigated biological processes their cooperation has been demonstrated, and there is good reason to suppose that they take part in all changes occurring within the living cell. So much is certain, the physiological chemistry of the future will be largely concerned with the study of fermentative changes; many indications that this must be the case are to be met with in tracing its latest developments.

The number of the enzymes has been increased to an extraordinarv extent during the last ten years. I may allude to the newly discovered enzymes correlated with the carbohydrates: maltase, lactase, mellibase, trehalase, amygdalase, inulase; to the various oxidases: laccase, tvrosinase: to the lipases, erepsin, enterokinase, arginase, the sucroclastic and glucosidoclastic enzymes, and finally to the zvmase of alcoholic fermentation. Much valuable information has been aecumulated as to the manner in which they act, as to their formation from zymogens, and as to their assistance by co-ferments and their retard ation by chemical agents or by anti-ferments. The specific haracter of their-action, in ather words, their dependence on the structure and configuration of the obiect they 
attack, has been proved beyond doubt, and favours very definitely the assumption that enzyme and hydrolyte enter temporarily into combination, a conclusion to which $\mathrm{H}$. E. Armstrong and E. F. Armstrong have quite recently again very properly directed special attention; but, unfortunately, we know practically nothing of the composition of the enzymes, as the complete isolation of an enzyme has never been accomplished.

From observations hitherto made, it appears in a measure probable that they are derived from proteins and possess a protein-like character. If this be so, it may be hoped that the experience gained with the proteins will be of service in the investigation of enzymes.

In the meantime, there are other directions in which synthetic chemistry can be of service in elucidating the chemistry of fermentation. In the same way that the artificial glucosides have been of use in establishing the dependence of the action of enzymes on configuration, the synthesised polypeptides are now being used by Abderhalden, Euler, and others to define and measure the activity of the proteoclasts. In a like manner, the synthetic exploration of the purine group has served to direct the recent observations on the fermentative de-amination and oxidation of adenine, guanine, and xanthine. Finally, attention may be directed to the use that has been made of stereochemical considerations in the course of Bertrand's interesting studies of the oxidation of polyhydric alcohols by the sorbose bacterium.

Not only have the methods of organic chemistry proved to be fruitful of results in the case of the proteins, but also when applied to complex derivatives of the latter, such as the nucleo-proteins, for example. Thus we are indebted to the brilliant researches of A. Kossel and his school for our knowledge of no less than four bases of the pyrimidine and purine group obtained by breaking down nucleic acids, and the analytical investigation of the latter has already been carried so far that, in the opinion of $\mathrm{H}$. Steudel, it is to be expected that their synthesis will be effected at no distant date. Similar success may be hoped for even sooner in the case of the lecithins. Structural chemistry, moreover, is slowly acquiring the mastery over cholesterin by making use of the experience afforded by the synthetic study of the hydroaromatic substances.

Besides the old well-known constituents of the animal body, new substances having quite unexpected properties have been added from time to time. Such are iodothyrin from the thyroid gland-discovered by Baumann-and crystalline adrenaline-isolated by Takamine from the supra-renal capsule-minute doses of which increase the blood-pressure. Judging from analytical results and the synthesis effected by F. Stolz, adrenaline possesses a relatively simple structure. In the opinion of the discoverers, this is probably true of the "pancreatic secretin" made known by Bayliss and Starling's researches, which has the remarkable property of liberating enzymes from the pancreas. May it not also be true of the toxins of many infectious diseases and of the antitoxins used in serum therapeutics, the discovery and systematic investigation of which by Behring, Roux, P. Ehrlich and others, are to be reckoned among the greatest achievements of modern biology and medicine?

The methods of organic synthesis will certainly serve to throw light on the nature of all such substances of animal origin. Equally numerous problems await solution in the plant world.

The great success with which the alkaloids and terpenes have been studied during the past ten years is known to all, but it is only too obvious that much still remains to be done when such substances as quinine, morphine, and caoutchouc remain to be synthesised.

Alizarin and indigo are prepared artificially in huge quantities, and we are well informed as to the structure of hæmatoxylia and kindred substances: but our ignorance is correspondingly great of most of the blood colouring matters, as well as of many coloured constituents of our own bodies-of the hair, the skin, and the eye.

The fullest recognition must be accorded, however, to recent investigations on the complex colouring matters of the blood and of chlorophyll, which is distantly related to the former: associated with the names of Schunck, Nencki, Marchlewski, Küster, and Willstätter.

Nก. I982, VOL. 76]
In fine, the aid of synthetical chemistry is required in every direction in arriving at a clear understanding of structure and of change. The methods at our disposal in the laboratory are doubtless altogether different from those which come into operation in the living world, but chemists are already trying to effect changes in carbon compounds by means of so-called mild interactions, under conditions comparable with those which prevail in the living organism. It may suffice to refer to the development of a number of catalytic processes and to the comprehensive studies on the action of light on organic substances undertaken by Ciamician. In fact, the effort is already being made to cooperate with biology; it is clear that a section of the forces of organic chemistry is being directed once more towards the goal from which it set out. The separation from biology was necessary during the past century while experimenta! methods and theories were being elaborated; now that our science is provided with a powerful armoury of analytical and synthetical weapons, chemists can once more renew the alliance both to its own honour and to the advantage of biology. Indeed, the prospect of obtaining a clearer insight into the wondrous series of processes which constitute animal and vegetable life may well lead the two sciences to work with definite purpose to a common end.

In order, as far as possible, to avoid mistakes in this difficult task and to shield ourselves from the disappointment which is the inevitable consequence of exaggerated hopes, we cannot do better than strive to imitate the great example of Faraday, who always, with rare acumen, directed his attention to actual phenomena without allowing himself to be influenced by preconceived opinion, and who in his theoretical conceptions gave expression only to observed facts.

\section{UNIVERSITN AND EDUCATIONAL INTE LLIGENCE.}

Cambridge. The Public Orator, Dr. Sandys, spoke as follows on Thursday, October 17, in presenting for the degree of Doctor in Science honoris causa Geheimrath Emil FIscher, F.R.S., professor of chemistry in the University of Berlin :-

Scientiae chemicae professor Berolinensis, purpura nostra (ut videtis) vestitus, ex insperato nobis hodie paulisper affulsit. Novimus tamen quam subtiliter materiam illam investigaverit, quae cum aqua commixta lanam colore roseo pulcherrimo tingit; novimus, via quam admirabil pedetemptim progressus, sacchari genera multa, aut olim nota aut $a b$ ipso patefacta, in elementa sua prima resolverit, atque atomorum de ordine et positura leges novas illustraverit. Peritis saltem nota sunt plurima alia viri huius inventa, quae scientiae intimae ad ipsa penetralia pertinent. Duo vero laboris eius monumenta multorum oculis sunt manifesta atque aperta. Berolinensibus praesertim patet Institutum illud magnum consiliis eius conditum; talium rerum studiosis ubique terrarum patet opus eius eximium sexies saltem in lucem editum. Virum igitur tam insignem et salvere et valere hodie libenter iubemus, qui Faradaii in memoriam orationem inter Londinienses propediem habiturus est, quique, studiorum communium consuetudine nobiscum consociatus, eo artiore nobiscum vinculo coniunctus est, quod filium suum natu maximum Universitati nostrae in scientia chemica erudiendum haud ita pridem commendavit

Duco ad vos virum in scientia chemica per orbem terrarum totum illustrem, AEmilium Fischer.

On Tuesday, October $\mathrm{x}_{5}, \mathrm{Mr}$. A. Henry, the reader in forestry, gave his inaugural lecture before a large audience. The Vice-Chancelor presided. Mr. Henry dwelt upon the causes which h/o retards t the scientific development of forestry in Grolaf Britip. types of foreg and feir origh, and the several methods of the mandf went of forests. He also described the rapidly apploching depletion of the forests in the United States and northern Europe, and pointed out the necessity of re-afforesting the waste lands of our country. He dwelt at length on the possible introduction of exotic trees, such as the western larch and the Corsican pine. In conclusion, $\mathrm{Mr}$. Henry described the course he purposed to 